\author{
Magdalena Filipczuk \\ http://orcid.org/0000-0001-7122-1837 \\ Akademia Ignatianum w Krakowie \\ mkalemba@interia.pl \\ DOI: $10.35765 /$ pk.2021.3504.06
}

\title{
Introducing Chinese Philosophy to Western Readers - Lin Yutang as a Cross-cultural Interpreter ${ }^{1}$
}

\section{AB STRACT}

The article reconstructs selected motifs in the philosophy of Lin Yutang, a twentieth-century Chinese thinker, translator and editor, especially popular in the West, undertaken, as it were, on the margins of his work to explain and popularize Chinese culture and philosophy in the West. Lin reflects on issues such as how to effectively and accurately explain a radically alien civilization to the Western-educated reader, in his or her own language, and who can appoint himself as the representative of Chinese culture at all? As a bilingual author, Lin very accurately shows the state of suspension between two cultures, characteristic of an intercultural interpreter who attempts to simultaneously move within two disproportionate, culturally determined conceptual schemes.

KEYWORDS : Lin Yutang, Chinese culture, intercultural translation, comparative philosophy

\section{STRESZCZENIE}

Przedstawianie chińskiej filozofii zachodnim czytelnikom - Lin Yutang jako tłumacz międzykulturowy

W artykule rekonstruuję wybrane wątki refleksji Lin Yutanga, popularnego, zwłaszcza na Zachodzie, dwudziestowiecznego chińskiego myśliciela, tłumacza i redaktora, podejmowanej niejako na marginesie jego pracy na rzecz objaśniania i popularyzowania chińskiej kultury i filozofii na Zachodzie. Lin zastanawia się nad następującymi zagadnieniami: W jaki sposób skutecznie, a jednocześnie trafnie opowiedzieć czytelnikowi wykształconemu w kulturze zachodniej, w jego własnym języku, o radykalnie obcej cywilizacji? Kto w ogóle może mianować samego siebie reprezentantem kultury chińskiej?

1 Funding Acknowledgments: The funding was generously provided by the National Science Center in Poland (project number: 2018/29/N/HS1/02681)

Suggested citation: Filipczuk, M. (2021). Introducing Chinese Philosophy to Western Readers - Lin Yutang as a Cross-cultural Interpreter. (c) (i) Perspectives on Culture, 4(35), pp. 87-104. DOI: $10.35765 /$ pk.2021.3503.06. 
Jako autor dwujęzyczny Lin nader celnie ukazuje stan zawieszenia, stan bycia pomiędzy, charakterystyczny dla tłumacza międzykulturowego, który podejmuje próbę jednoczesnego poruszania się w obrębie dwóch niewspółmiernych, kulturowo zdeterminowanych schematów pojęciowych.

SŁOWA KLUCZE: Lin Yutang, kultura chińska, przekład międzykulturowy, filozofia porównawcza

\section{The specter of Eurocentrism}

Already in the introduction to the 2014 Civilizations and World Order: Geopolitics and Cultural Difference, the editors note that

There is a deeply felt need for a new understanding of global order which can accommodate... different globalization experiences of reviving civilizations (Dallmayr, Kayapınar, \& Yaylacı, eds., 2014, p. xi).

The challenge of our time is to supposed to be limited to: "an inclusive civilizational self-perception;" "a new epistemological harmonization;" "a new harmonious balance between values and social mechanisms;" an all-embracing re-assessment/re-interpretation of the human history (Dallmayr, Kayapınar, \& Yaylacı, eds., 2014, p. xii). China's dominant position in geopolitics has the eyes of the world today moving towards this country, far too poorly represented in the international arena; "China's case" is being constantly redefined (cf. Janik, 2020). There is no doubt that the dia$\log$ between civilizations has become a matter of first importance, however, more and more questions are raised about the shape it would take. Many still believe that it is enough, while remaining superior, to allow China to the fore in the debate, the rules of which are already predetermined by us, the participants of Western civilization. It seems that people in the Western world still have the hardest time being willing to verify or question the very definition of what matters and what is considered important in light of other traditions and other cultures. Meanwhile, without an open mind and knowledge, it will be difficult to understand the Chinese idea of intercultural dialog or even the so-called Chiglobalization, i.e. "globalization with Chinese characteristics" ${ }^{2}$ and the related idea of the New Silk Road. ${ }^{3}$

A derivative of this state of affairs is a debate taking place within philosophy. The last decade has seen a discussion about a profound reform

2 This concept was introduced by Wenshan Jia. Cf. Jia, 2010 and Jia, 2017.

3 More in: Molavi, 2015; Nobis, 2016; the idea of the Silk Road from a philosophical perspective is repeatedly taken up by a prominent Chinese philosopher, Peimin Ni $(2015 ; 2018)$. 
of philosophical studies, and consequently, of the canon shaped at a time when it could still be taken for granted, that "philosophy is, quite simply, a Western matter" (Defoort, 2001). Researchers in comparative philosophy stress that, according to the state of research in the twenty-first century, the philosophy taught at European universities should rather be called "General Western Philosophy" (Defoort, 2001), and they therefore suggest "renaming" departments and calling them "departments of European and American philosophy" (Garfield \& Van Norden, 2016), as there is still insufficient attention paid to non-Western cultures in many of them:

Most philosophy departments also offer no courses on African, Indian, Islamic, Jewish, Latin American, Native American or other non-European traditions. Indeed, of the top 50 philosophy doctoral programs in the English-speaking world, only 15 percent have any regular faculty members who teach any non-Western philosophy. Given the importance of non-European traditions in both the history of world philosophy and in the contemporary world, and given the increasing numbers of students in our colleges and universities from non-European backgrounds, this is astonishing. No other humanities discipline demonstrates this systematic neglect of most of the civilizations in its domain. The present situation is hard to justify morally, politically, epistemically or as good educational and research training practice (Garfield \& Van Norden, 2016).

Making philosophy a more diverse and multicultural discipline by, among other things, extending the philosophical canon to include the works of such authors as Confucius, Laozi and Chandrakirti is undoubtedly one of the major challenges for the field in the 21st century (cf. Van Norden, 2017; Ni, 2016). To what extent does the enrichment of the Western subject matter of philosophy with hitherto underrepresented philosophical currents and theoretical perspectives peculiar to various races and peoples entail a transformation of the problematic of philosophy, or even a redefinition of it? This is why Leigh Jenco, a researcher of Chinese philosophy, notes

the deep irony of much cross-cultural work in the contemporary Western academy: research into "global" thought seeks inclusion of diverse cultural perspectives, but does so by means of those very discourses whose cultural insularity is what prompts critique in the first place (Jenco, 2007, p. 741).

Moreover, the author suggests that

looking at culturally situated methods of inquiry, in addition to substantive ideas, can reinterpret cross-cultural engagement as an opportunity to 
ask new questions through alternative frames of reference (Jenco, 2007, p. 741).

\section{Lin as a cultural interpreter ${ }^{4}$}

Lin Yutang (Lin Yu-tang 林语堂, 1895-1976), a linguist, thinker, essayist, writer, and translator did not hesitate to propose such an alternative frame of reference to the Western reader. He published works such as My Country My People and The Importance of Living as early as the 1930s. Lin is an unusual figure in many respects - he was a great erudite and was interested in a variety of topics, which resulted in his achievements in many fields. Educated in both China and the West, Lin was a bilingual author. He published primarily in English ${ }^{5}$ with an eye toward a Western readership, devoting much of his life to the work to deepen the understanding of Chinese culture by participants in Anglo-Saxon culture. He gained popularity in the United States as a "Chinese philosopher," and "a wise man from the East” (Qian, 2015, p. 2). In the 20th century, he was also the most popular Chinese intellectual in the United States, surpassing even Lu Xun (Lu Sun 周樟壽, 1881-1936) and Hu Shi (Zhu Xi 朱喜, 1130-1200): ${ }^{6}$

Lin's diverse background ... equip him to interpret China for millions of Americans. Lin assumed the role of mediator or cultural translator: in presenting himself as a representative of a foreign culture, he simultaneously portrayed China in terms that were familiar and comprehensible to his American readership (Handler-Spitz, 2015, p. 145).

4 Cultural translation is understood here as "the transfer of concepts and values - not words alone (although words are always infused with cultural significance) - from one culture into another. Etymologically «translation» is identical to «transfer»: both words derive from the Latin roots trans/across, and fero, ferre, tuli, latus/to bring or carry. Translation, then, can be construed as a «carrying across» of ideas between cultures. To the extent that The Importance of Living strives to introduce aspects of traditional Chinese culture and «wisdom» to an American audience, this book embodies the spirit of what we may call cultural translation” (Handler-Spitz, 2012, p. 123).

5 Lin Yutang wrote more than thirty books of non-fiction in English, mainly of a philosophical nature. Cf. Jin, 2008, p. 12.

6 Cf. Chapter Six in Oriental Other: The Business of Translating Chinese and American Cultures in Qian, 2011. On Lin as an interpreter of Chinese culture see, for example, Laughlin 2015 and Qian, 2015. On Line as a translator, cf. Ping Li, 2012 and Yangyang, 2018. Given the multiplicity and complexity of Lin's cross-cultural practices, it is hard to argue that, nearly a century after the publication of his seminal works, interpreting his thought is still difficult for critics. As we read in a monograph on Lin: "it takes a community of scholars from different cultural backgrounds to engage in cultural critique on Lin's cross-cultural practices” (Qian, 2015, p. 9). 
It was mainly his focus on the Western reader that caused Lin to arouse much controversy in his own country. ${ }^{7}$ Similarly to Ku Hung-ming (Gu Hongmin 幸鴻銘, 1857-1928), Thomé H. Fang (Fang Dongmei 方東美, 1899-1977); Wing-tsit Chan (Chen Rongjie 陳榮捷, 1901-1994) or Feng Yu-lan (Feng Youlan 馮友蘭, 1895-1990), Lin created an individual strategy of explaining and popularizing Chinese philosophy in the West. In the time when the average American was not familiar with either Chinese culture or philosophy, Lin played a huge role as a cross-cultural translator between China and the West. Called "a cultural bridge between East and West" (Ping Li, 2012, p. 2); and a "promoter of Chinese culture internationally" (Ping Li, 2012, p. 2):

Lin was first and foremost a translator, a mediator between two languages and two cultures, wrestling with the inherent tension between foreignization and domestication, between accurate translation and artistic representation, and between form and function. As a theorist, he succeeds in discarding the futile dichotomy between literal translation and free translation. As a critic, he succeeds in establishing a purpose-driven, constructive critique for translation. And as a translator, he succeeds in expanding the unmapped world between Chinese and English in both the linguistic and cultural dimensions (Ping Li, 2012, i).

Already in the Prologue to his first monograph, written in English and entirely devoted to China, Lin assigns himself the role of representing China: "Between being well understood ... and being called great, China would have preferred the former, and it would have been better for everybody all round. But how is China to be understood? Who will be her interpreters?" (Lin, 1936, p. 7). The question is a non-trivial one, especially if Lin is right when he posits, along with many Chinese scholars of the time, the diagnosis that: "It is the lot of the great to be misunderstood, and so it is China's lot. China has been greatly, magnificently misunderstood" (Lin, 1936, p. 7). Thus, the question of who would be the proper translator/ interpreter is one that Lin devotes considerable space to in his early work, presenting it as almost inconclusive:

7 As for his reception in China, Lin for much of his life was boycotted by the government and the state-owned newspapers as a critic of Communism and promoter of improper (from the point of view of the authorities) themes of Chinese culture. Rather, Lin's work was appreciated by those Chinese scholars who themselves made this attempt, partly doomed to failure, to simultaneously competently and attractively translate the patterns of Chinese culture in terms of the Western reader. Such scholars include Tsit-Wing-Chan, who not only devotes much space to Lin as a critic and interpreter of Chinese culture (Chan, 1940; 1945; 1947), but gives him due homage in his compendium A Source Book of Chinese Philosophy (Chan, 1963), mentioning his work as "excellent studies" in his narrow bibliographic list. 
The true Europeans in China do not speak Chinese, and the true Chinese do not speak English. The Europeans who speak Chinese too well develop certain mental habits akin to the Chinese and are regarded by their compatriots as "queer". The Chinese who speak English too well and develop Western mental habits are "denationalized," or they may not even speak Chinese, or speak it with an English accent (Lin, 1936, p. 8).

Reflecting on similar issues, the eminent French sinologist François Jullien wrote that "strategies of meaning can only be understood from the inside, by following their internal logic" (Jullien, 2000, p. 9). Lin there is even more radical: To be able to competently explain China to the West, one must speak about its culture from an insider's position. Even the best knowledge from books is no substitute for growing up and being raised in China; even the longest trip to China is not enough to become a competent interpreter. Lin presents the newcomers usurping the role of interpreters of China in a distorted mirror. Although they often try to assimilate, they still have the mentality of a tourist (cf. e.g. Lin, 1936, p. 8). Members of the community are also Western scholars of China: sinologists and bibliophiles who, according to Lin, mistakenly perceive Chinese culture through the prism of the Confucian classics (Lin, 1935, pp. 7-8). Because such outsiders speak about China in the West, misunderstandings abound, which Lin ironically describes repeatedly in the pages of his writings. According to him, such erroneous stereotypes include the claim that China is culturally stagnant or that the Chinese enjoy primitive living conditions and do not know what progress is (Lin, 1936; Lin, 1939). For Lin, such statements result from a "misconception of one looking at China from the outside, without knowledge of her inner life" (Lin, 1936, p. 38), and above all, from failing to understand that what is the ideal life for a Chinese person, and therefore, a different perception of progress or good living conditions from the American one.

That ideal of life is revealed to a member of a cultural community through bringing up. The story of Lin's youth, however, is different from that shared by most of his Chinese peers: as the son of a missionary, he received an excellent Western education and, by his own admission, he realized after many years of study that his knowledge of Chinese writings was "half-baked" (Lin, 1975, p. 31), and then he threw himself into learning about Chinese culture. ${ }^{8}$ It seems that due to the fact that neither the Chinese education nor the sense of belonging to Chinese high culture were given to Lin in advance, by virtue of birth alone, and his Chinese identity

8 Speaking about the years 1916-1919. For more about this period of Lin's life cf. Christian Childhood and Westernized Education in Qian, 2017. 
in his writing is an element of self-creation, ${ }^{9}$ a bargaining chip enabling him to speak on behalf of China. Lin exposes himself as an interpreter shaped by his personal experience of identity crisis. The reflection on what it means to be Chinese in the 1930s and 1940s in his case has a personal dimension and develops in contrast to what is foreign and what - as he says teasingly, he never mastered and did not recognize it as fully natural. ${ }^{10}$ Recalling the years of his youth, he recalls about his search:

So my grand detour began. At first it made no sense to me. Trained in the modem weapon of thought like any college graduate, my mind had to flash across the continents of thought, and found them strange, or uninteresting or jejune. (Confucius always sounds a little jejune at first.) (Lin, 1959 , p. 63)

Paradoxically, then, focusing on the alien and then finding that he cannot identify with that alien, enables Lin to perform a deeper, critical self-identification. Accordingly, Shaner writes:

One must recognize that cultural boundaries are meaningful only against the background of noticing differences between language, culture, and history. Hermeneutic theories must not suggest that to understand others one needs to leave home and live in the desert of the between. Quite to the contrary, it is only on the basis of one's keen awareness and sense of place (in space, time, and culture) that one develops a sensitivity to that which is other (Shaner, 1986, p. 144).

We find many such paradoxes in Lin's work: through English and even German languages, ${ }^{11}$ he analyzes classical Chinese; his philosophical language is firmly grounded in classical English, yet Lin models the style of the Chinese essay. In Lin's work, therefore, we are not dealing with the author positioning himself as a transcultural subject above the juxtaposed planes of different traditions, ${ }^{12}$ which was characteristic of comparative works published in the West in the first half of the twentieth century. Whether one wants to interpret Lin Yutang's writings from the perspective

9 Some critics thoroughly analyze the aspect of the creation of Lin's Chinese identity in consultation with publishers, also on the basis of the correspondence between Lin and his publishers, and his other letters. Cf. e.g. Qian, 2012; Qian, 2015; So, 2010.

10 Cf. chapter The Grand Detour Begins in Lin, 1959.

11 Written in German and defended at the University of Leipzig, Lin's doctoral dissertation titled Altchinesiche Lautlehre (Ancient Chinese Phonetics) concerned the Chinese classical philology.

12 Some researchers situate Lin Yutang in the context of transculturalism. Cf. e.g. Ricci, 2013. 
of psychology, philosophy, or literary theory and criticism, it is clear that they are written somewhere between the Chinese Self and the Atlantic-Western Other. It is no exaggeration to say that it is this state of being in-between that enables Lin to philosophize across boundaries ${ }^{13}$ and to shape a philosophical self. ${ }^{14}$

\section{Creation of China}

As a linguist, Lin is aware that language is a particularistic creation even within the boundaries of a single culture. One can also successfully talk about China in the language of taoists, liberals, Confucians or Buddhists. Preventing possible accusations, ${ }^{15}$ in the introductions to his books, Lin stipulates that he does not aspire to universality, stressing that what he chooses from the whole range of meanings associated with the Chinese culture is subjective or even idiosyncratic in nature. His story grows out of an individual and concrete point of view (Lin, 1937, p. vii), for how China appears to someone depends, first and foremost, largely on the beholder himself: "China is too big a country, and her national life has too many facets, for her not to be open to the most diverse and contradictory interpretations. And I shall always be able to assist with very convenient material anyone who wishes to hold opposite theses" (Lin, 1936, p. xiii).

As noted by one of the researchers:

More than just informing Western readers about China ... Lin is affirming a particular vision of Chinese cultural identity and what he would call the Chinese "philosophy of life," one that is based to a large degree in literary traditions, and specifically in a certain unconventional canon of literature.... Chinese authors that even well-educated English readers could not possibly contextualize within the categories of "Chinese culture" available to them or through other meager sources of knowledge and information about China. Thus, in effect, Lin was in the business of "creating" China in a certain mold for English readers who had little or nothing else to go on (Laughlin, 2015, p. 39).

13 Cf. title of the book by G. Larson and E. Deutsch (eds.) (1989). Interpreting Across Boundaries. New Essays in Comparative Philosophy. Delhi.

14 More about the formation of the philosophical self in Lin Yutang, I wrote in: Modeling "self" through writing. Lin Yutang as a philosopher of the art of life. [In print].

15 Among other objections (cf. Chan, 1947; Qian, 2015; Qian, 2011), Lin was accused of treason against the Chinese people, characterizing almost exclusively Chinese elites, presenting this characteristic as a credible portrait of the Chinese nation. 
One should not forget, then, that Lin published in the United States from the position of a cultural outsider, writing in the most exotic of foreign languages and attempting to gain the interest of Americans in a cultural background they did not value much. With such scant knowledge, China's interpreter becomes a creator who, to borrow a phrase from Jullien, "draws up a map of meaning in China" (Jullien, 2000, p. 11). One researcher puts it in a similar way, stating that Lin manages to expand the "unmapped world between Chinese and English" (Ping Li, 2012, p. i). The imagery associated with the mapping here is not accidental. If we do not have maps, we create one by drawing it, not mapping. In other words, Lin deals with the transfer of the burden of studying the reality into what Jullien calls "constructing meaning." Constructing meaning through by Lin is accompanied by methodological reflection, in which the author/ interpreter comes to the fore.

\section{Disparity between culture systems}

In Lin's narrative, the Chinese cultural community is not only a linguistic one, but also a thought system, a belief system (in Lin's terms, the "Chinese mental make-up"), and a community of specific forms of daily life that grow out of a philosophy of life. Much later, the British philosopher Alasdaire MacIntyre, argued that to belong to a community is to share "schemata which are at one and the same time constitutive of and normative for intelligible action by myself and are also means for my interpretation of actions of others" (MacIntyre, 1977, p. 454). According to him, these cultural systems are incommensurable - they have separate schemes for rationally justifying beliefs. This would mean that some areas of reality and some of the Chinese beliefs as members' of an isolated cultural community are basically untranslatable into another community. And while many utterances in one language can be translated into another, a specific cultural tradition is constituted by those features of linguistic competence that are the source of untranslatability: those forms of life that evoke surprise in the tourist, as well as those beliefs that are deeply embedded in world views or patterns of reasoning.

But how can one think of a linguistic community in China, given the dominance of Mandarin along the hundreds of dialects that make the experience of cultural belonging of their users originate outside these dialects? It seems that Lin's answer to this question too is very similar to how MacIntyre later answered it. Whether or not one is a member of a given language community is determined by one's drawing on the stock of canonical texts that define the cultural heritage of that community. 
Heritage, created by poets, writers, thinkers and artists, creates what we call here cultural tradition. MacIntyre argues that this is where the source of a community's conceptual resources defining much of its consciousness must be sought: the concepts and ideas constitutive of that community or culture function first in its "great" foundational texts.

Just as - in MacIntyre's interpretation - the Anglo-Saxon tradition is "founded" on such notions as courage, justice or authority, shaped, among others, by Horace's writings, ${ }^{16}$ so, in the case of China, an important role is played by cultural patterns that the Chinese derive from the great texts of their culture, i.e. the so-called Confucian canon. ${ }^{17}$ Today, these books are considered to be "meaning-making machines", sources not only of classical cultural codes but also of contemporary Chinese thought. It is no coincidence that a significant portion of the corpus of these texts has been translated into English and interpreted by Lin, ${ }^{18}$ and he believes that in the case of works such as Confucius' Dialogs (Lunyu 論語), translation is indistinguishable from paraphrase, and that paraphrase is the best and most satisfying translation method (Lin, 1938, p. 48). On the sidelines of his translation work, he notes:

Speaking English, one thinks in English, and speaking in Chinese one thinks inevitably in Chinese. If I were to write two essays one morning on the same subject with the same ideas, one in English and the other in Chinese, the essays themselves would come out differently because the flow of thought, following different imagery and allusions and associations, would automatically lead into different avenues. Man does not talk because he thinks, but thinks because he talks, because he has no words to play with and thinking is only the tumbling about of words. The ideas themselves come wearing a different dress and complexion when one speaks a different language because the words have a different timbre and different associations. Hence, studying Chinese, I began to think as a Chinese .... The leap between the two languages so different as the Chinese and the English was somewhat bizarre (Lin, 1959, p. 59).

Elsewhere, Lin writes that a Chinese who speaks English too well unwittingly develops mental habits that belong to the West (Lin, 1937, p. 8; Lin, 1959). Recalling Nisbett's contemporary statements, the attempt to simultaneously navigate within two incommensurable, culturally determined conceptual schemes entails changing the geographies of thought fixed in

16 For more on this, cf. MacIntyre, Tradition and Translation in MacIntyre, 1988.

17 Canon may be understood as a set of statements by wise men, to which successive generations of Chinese thinkers wrote comments. For more on this, cf.: Nylan, 2001.

18 See Lin, 1938; 1944; 1967; 2012; 2014. 
our minds by various social practices (Cf. Nisbet). For example, describing the Chinese (ideal) character, before discussing the Great Learning (Daxue 大学) by Confucius, Lin notes that:

"Character" is a typically English word. ... Totally devoid of any extramundane interests, and without getting involved in any religious claptrap, this ideal of building of character has, through the influence of their literature, the theatre, and proverbs, permeated to the lowliest peasant, and provided him with a philosophy of life. But while the English word "character" suggests strength, courage, "guts," and looking merely glum in moments of anger or disappointment, the Chinese word for "character" brings to us the vision of a mature man of mellow temperament, retaining an equanimity of mind under all circumstances, with a complete understanding not only of himself but of his fellow-men (Lin, 1936, p. 38).

In this regard, one should ask how to avoid de-contextualization that is often the result of translation. As a result of this de-contextualization, the beliefs of the members of another community may appear to lack rational justification. How do we avoid reducing content to what is considered momentous and important in the reader's culture? In Lin's case, his translations and commentaries approximate the meanings of terms used by Chinese artist-philosophers and other figures important to Chinese culture. Instead of looking for equivalents of concepts crucial for Western philosophy in Chinese texts, he familiarizes the Anglo-Saxon reader with the untranslatable categories that make up the Chinese world view, such as: $d a o$ (道); de (德), $l i$ (理); wuwei (无为), $q i$ (气) and others ${ }^{19}$ ). In this context, Maurycy Straszewski's suggestion to think of the concepts of a foreign culture as whole elements, separate "organisms of concepts" 20 which become intelligible to us when we begin to penetrate their contextual meaning. Importantly, Lin argues that a clear translation is not only possible, but it is the translator's duty, since, according to him, it is perfectly intelligible in the perception of the Chinese: ${ }^{21}$

19 At the end of several of his monographs, Lin included glossaries of his own authorship containing key terms. For many years, Lin also worked on his own Chinese-English dictionary, Lin Yutang's Chinese-English Dictionary of Modern Usage (1972). For more on this, see Ching and Qian (2011).

20 According to the then (nineteenth century) diagnosis, Straszewski proposed a general division of human thinking into three types of separate conceptual organisms: the European type, the Chinese type and the Indian type. They were supposed to develop separately and to some extent in parallel with the respective civilizations (as cited in: Jakubczak, 2013, p. 349).

21 A very similar thesis is put forward by a Chinese philosophy researcher, Anna Iwona Wójcik. Namely, she shows that the "mystery" that we assign to the texts of Chinese culture results from appending contexts of the meaning of western philosophy to them, while in the Chinese texts 
The choice of a single wrong word in translation may throw a whole paragraph into obscurity. Granted that Chinese literary concepts are often strange to Western students and the expressions baffling, it should be remembered that they are perfectly clear to the Chinese, and it is the duty of the translator to convey their meaning clearly (Lin, 1967, p. 4).

\section{Philosophizing in a comparative perspective}

In the twenty-first century, philosophical comparative studies have been dominated by detailed analyses: one studies primarily specific philosophical currents in relatively small time frames, the works of individual authors, or narrowly defined (sub)cultures. The universalizing syntheses attempting to capture entire systems of thought, the peculiarities of the "Orient," the characteristics of the "peoples of Asia," the attitudes, character, or way of thinking of an inhabitant of the "Far East" are passing into oblivion. ${ }^{22}$ However, even the fact that Lin wrote his most important works in the 1930s and 1940s, when comparative studies were in their seed stage, does not provide a convincing explanation for his predilection for generalization and contrast.

An interesting suggestion in this context is made by Wing-tsit Chan, a Chinese scholar living in the twentieth century, best known for his monographs on Chinese philosophy and translations of Chinese philosophical texts, indicating that Lin is a critic of both the Chinese and the American way of life, in the sense that a philosopher can be considered precisely a critic of life (Chan, 1947, p. 1). Lin would need generalizations, then, primarily as a rhetorical strategy with a therapeutic dimension: it would be a matter of "juxtaposing" foreign categories of thought and perception with those from which the reader emerges, thereby - indirectly gaining cognitive distance from his own thought and what shapes it. The effect of such juxtapositions would be to "defamiliarize" one's own culture and its social and artistic practices. Defamiliarization done in order to view these practices from a global perspective. In this light, it becomes

we are dealing with a different basic interpretation model. He points out that when we examine the patterns of reasoning from which Chinese thinkers and artists draw, we find that we are dealing with "a coherent and completely understandable system of concepts. A system radically different from Plato and Aristotle, but also clear and comprehensible” (Wójcik, 2010, p. 21).

22 This can be seen even the titles of the books. Back in the 1940s, one of the most influential books in the West was the monograph by F.S.C. Northrop (1946). The Meeting of East and West (New York). Later, in the 1960s, many monographs were written that included detailed studies of the types of mentalities that characterize different nations: Moore, ed., 1967; Johnson, 1972; Moore, ed., 1968; Wal-dal Yang, 1982. One of the most well-known is Nakamura, 1964. 
understandable why Lin is less likely to use the analog method, conceived as a search

the relations of equivalence between ideas, notions, concepts and mindsets that have emerged over the centuries in the philosophical traditions of geographically, politically, and linguistically isolated cultures: the European, the Indian, and the Chinese (Jakubczak, 2013, p. 344),

he much more often reaches for the contrasting method, which allows him to call into existence a model of the Other. Regardless of Lin's analysis of the topic (e.g. attitude, ideals, character, mental habits), it will move between two opposing poles, one of which is Chinese/ Oriental/ Eastern, while the other, respectively - English/ European/ American/ Western. By presenting a philosophical conceptualization "in English" of a lifestyle developed in Chinese, Lin points to the contextualization of lifestyles taken for granted and obligatory in the West, thereby not explicitly questioning the beliefs developed within Anglo-Saxon culture, but rather giving them the status of a universally valid interpretive framework.

One clue to the therapeutic purpose of Lin's writing is his inspiration by Michel de Montaigne's rhetorical strategies from his Essays, such as those encountered in the famous essay on cannibals and the text describing an encounter between one of the "savages" and the King of France. As pointed out by Rivi Handler-Spitz, the author of numerous works on Chinese writings from a comparative perspective, both authors, in undertaking the work of cultural translation, make a subtle yet insightful critique of their readers' most fundamental and deeply held (though often poorly researched) beliefs. Thus, Montaigne introduces the reader to an alien culture that the reader is presumably inclined to view as primitive, brutal, and repulsive. However, by manipulating the perspective in unexpected ways, he presents the "savage" tribe in a surprisingly balanced way and leads the reader not only to tolerate but even to identify with its representatives. In the essay, Montaigne smuggles in an implicit critique of the reader's native culture, prompting a reconsideration of his or her own previously unexamined assumptions about the supposed cultural superiority of Westerners over members of the "savage" tribes of South America. Handler-Spitz notes that in The Importance of Living, Lin employs similar strategies: under the guise of introducing a foreign culture, he challenges the reader's Western prejudices. According to the researcher, there is a parallel between the ignorance, disgust, and fear that Brazilian cannibals evoked in sixteenth-century Frenchmen and the feelings and associations Americans of the 1930s associated with the Chinese. Representing China, Lin Yutang tried to present his nation in a way that would 
overcome the deeply rooted stereotypes. Both authors were thus engaged in fundamentally similar projects: they sought not only to broaden their understanding of another culture, but they also wanted to challenge or at least put many of the assumptions of the Western reader to the test. ${ }^{23}$ Thus, it turns out that the contrasting is carried out in a rhetorically conscious and sophisticated manner, most likely inspired by the best tradition of wise doubting available in European high culture. By superimposing the Chinese tradition of thought on the grid of Western philosophical and cultural concerns, Lin allows China to act as a mirror through which Westerners can better examine themselves. According to Jullien's observation, "China presents a case study through which to contemplate Western thought from the outside - and, in this way, to bring us out of our atavism ... A theoretical distancing is desirable - and this is exactly what China offers" (Jullien, 2000, p. 9).

\section{Summary}

This is how Lin summed up the paradoxical task he was carrying out all his life in 1959: "One mind seeks the learning of ancients and moderns; Two legs straddle the cultures of East and West." I had to interpret the Chinese conscience and intuitive perceptions in the more exact frame of logical thinking, and subject the propositions of Western thinking to the test of Chinese intuitive judgment" (Lin, 1959, p. 63).

Like many other metaphorical structures in Lin's work, this one also aptly depicts the state of limbo, of being in between, a characteristic of the cross-cultural interpreter. The mission he set for himself - to add China to the world map of culture and philosophy - was not limited to publishing books of his own. Lin did a tremendous amount of editing, translating, popularizing, and research work. Sparing no effort, he worked on the Chinese characters typewriter ${ }^{24}$ and the subsequent parts of the Chinese-English dictionary, paving the way not only for the then but also future generations of scholars. He wrote: "the business of trying to understand a foreign nation with a foreign culture, especially one so different from one's own as China's, is usually not for the mortal man" (Lin, 1936, p. 7).

As I have shown, even a cursory recapitulation of the threads of Lin Yutang's thought reveals that he was well aware of the complexity of issues related to the interpretation and cross cultural understanding of facts and

23 More in: Handler-Spitz, 2012; 2015.

24 He devoted many years of his life to the work on this invention. For more on this, see Williams, 2010. 
phenomena belonging to different orders and traditions. In the case of this author's thought, the observation that comparing different philosophical traditions is not so much about reducing them to an alleged "common denominator," but rather about the type of philosophizing that consciously refers to a broadly defined comparative perspective in order to reveal the individual character of the phenomena under examination, and it proves to be true (cf. Botz-Bornstein, 2006). Only against such a background, that is, in a comparative context, can we see the specificity of individual traditions as historically and geopolitically conditioned in the right light, including the one in which we ourselves are immersed, and understand them more deeply.

\section{REFERENCES}

Botz-Bornstein, T. (2006). Ethnophilosophy, Comparative Philosophy, Pragmatism: Toward a Philosophy of Ethnoscapes. Philosophy East and West, January, vol. 56, no. 1 .

Chan, W. (1940). The Wisdom of Confucius by Lin Yutang. Pacific Affairs, 13(4), 483-487.

Chan, W. (1945). Laotse, the Book of Tao, The Wisdom of China and India by Lin Yutang. Journal of the American Oriental Society, 65(3), 210-211.

Chan, W. (1947). Lin Yutang, Critic and Interpreter. The English Journal, $36(1), 1-7$.

Chan, W. (ed.) (1963). A Source Book of Chinese Philosophy. Princeton: Princeton University Press.

Ching, E. (1975). [A review of] Chinese-English Dictionary of Modern Usage (by Lin Yutang). Journal of Asian Studies, 34.2, 521-524.

Dallmayr, F.R., Akif Kayapınar, M., \& Yaylacı, I. (eds.) (2014). Civilizations and World Order: Geopolitics and Cultural Difference. Lanham, Boulder, New York, Toronto, Plymouth, UK: Lexington Books.

Defoort, C. (2001). Is There Such a Thing as Chinese Philosophy? Arguments of an Implicit Debate. Philosophy East and West, vol. 51, no. 3.

Garfield, J.L. \& Van Norden, B.W. (2016). If Philosophy Won't Diversify, Let's Call It What It Really Is. The New York Times (access: 10.12.2016).

Handler-Spitz, R. (2012). The Importance of Cannibalism: Montaigne's Essays as a Vehicle for the Cultural Translation of Chineseness in Lin Yutang's The Importance of Living. Compilation and Translation Review, vol. 5, no. 1.

Handler-Spitz, R. (2015). Chapter Seven: Collaborator or Cannibal? Montaigne's Role in Lin Yutang's Importance of Living. In S. Qian (ed.), The 
Cross-Cultural Legacy of Lin Yutang: Critical Perspectives. Berkeley: Institute of East Asian Studies, University of California.

Jakubczak, M. (2013). Komparatystyka na gruncie filozofii. Założenia, uprzedzenia i perspektywy. Archiwum Historii Filozofii i Mysli Spotecznej, t. 58.

Janik, M. (2020). Imagining Immanent Causality: Depictions of Neo-Confucian and Spinozist Monism in the Works of Matteo Ricci and Pierre Bayle. Philosophy East and West. Published electronically November 5, 2020. DOI: 10.1353/pew.0.0206.

Jenco, L.K. (2007). What Does Heaven Ever Say? A Methods-centered Approach to Cross-cultural Engagement. The American Political Science Review, vol. 101, no. 4.

Jia, W. (2010). Chiglobalization? A Cultural Argument. In S. Guo \& B. Guo (eds.), Chiglobalization. Greater China in an Era of Globalization. Lanham: Rowman.

Jia, W. (2017, Jun. 7). Now, globalization with Chinese characteristics - Analysis. Eurasia Review. Retrieved from: http://www.eurasiareview. com/07062017-now-globalization-with-chinese-characteristics-analysis.

Johnson, W.B. (1972). The Austrian Mind: An Intellectual and Social History 1848-1938. Los Angeles: University of California Press.

Jullien, F. (2000). Detour and Access. Strategies of Meaning in Greece. New York: Zone Books.

Laughlin, Ch. (2015). Chapter Two: Lin Yutang's Unique Adoption of Tradition. In S. Qian (ed.), The Cross-Cultural Legacy of Lin Yutang: Critical Perspectives. Berkeley: Institute of East Asian Studies, University of California.

Li Ping (2012). A Critical Study of Lin Yutang as a Translation Theorist. Translation Critic and Translator. City University of Hong Kong.

Lin, Y. (1937). The Importance of Living. New York: Reynal \& Hitchcock.

Lin, Y. (1938). The Wisdom of Confucius. New York: Carlton House.

Lin, Y. (1944). The Wisdom of China. London: Michael Joseph Ltd.

Lin, Y. (1949). The Wisdom of China: an anthology compiled and annotated by Lin Yutang. London: Michael Joseph.

Lin, Y. (1959). From Pagan to Christian. Ohio: World Publishing.

Lin, Y. (1967). The Chinese Theory of Art: Translations from the Masters of Chinese Art. New York: G.P. Putnam's Sons.

Lin, Y. (2012). The Little Critic. The Bilingual Essays of Lin Yutang. Compiled and edited by Qian Suoqiao. Jiuzhoupress.

Lin, Y. (2014). The Wisdom of Laotse. Beijing: Foreign Language Teaching and Research Press.

Lin Yutang's Chinese-English Dictionary of Modern Usage (1972). The Chinese University of Hong Kong.

MacIntyre, A. (1977). Epistemological Crises, Dramatic Narrative and the Philosophy of Science. Monist, 60: 4. 
MacIntyre, A. (1988). Whose Justice, Whose Justice? Which Rationality? Indiana: Notre Dame.

Molavi, A. (2016). Five Ways the "New Silk Road' Could Transform the Global Economy. Credit Suisse, 27.11.2015. Retrieved from: https://www.credit-suisse.com/us/en/articles/articles/news-and-expertise/2015/11/en/ fiveways-the-new-silk-road-could-transform-the-global-economy.html (access: 10.11.2020).

Moore, Ch. (ed.) (1967). The Chinese Mind: Essentials of Chinese Philosophy and Culture. Honolulu: University of Hawai'i Press.

Moore, Ch. (ed.) (1968). The Japanese Mind: Essentials of Japanese Philosophy and Culture. Honolulu: University of Hawai'i Press.

Nakamura, H. (1964). Ways of Thinking of Eastern Peoples India-China-Tibet-Japan. Honolulu: University of Hawaii Press.

Ni, P. (2015). The Underlying Philosophy and Impact of the New Silk Road World Order. WPF Dialogue of Civilizations, 16 October.

Ni, P. (2016). Cultivation of Humanity through Stretching Liberal Arts Education, co-authored with Jiahong Chen. In M.P. Ford \& S. Rowe, From Liberation to Civilization: Seizing an Alternative Education. Process Century Press.

Ni, P. (2018). The Silk Order and Its Likelihood From a Philosophical Perspective. The Institute of Dialogue of Civilizations. Retrieved from: https://doc-research.org/en/silk-order-philosophical-perspective.

Nisbett, R.E. (2003). The Geography Of Thought. How Asians And Westerners Think Differently... And Why. New York, London, Toronto, Sydney, Singapore: The Free Press.

Nobis, A. (2016). Nowy Jedwabny Szlak: nowa globalizacja? The Polish Journal of the Arts and Culture, New Series 4 (2).

Northrop, F.S.C. (1946). The Meeting of East and West. New York.

Nylan, M. (2001). The Five “Confucian” Classics. New Haven: Yale University Press.

Qian, S. (2011). Liberal Cosmopolitan: Lin Yutang and Middling Chinese Modernity. Leiden-Boston: Brill.

Qian, S. (ed.) (2015). The Cross-Cultural Legacy of Lin Yutang: Critical Perspectives. Berkeley: Institute of East Asian Studies, University of California.

Ricci, R.J. (2013). What Make the Man? Towards a Psychobiographical Study of Lin Yutang. PhD Thesis. School of Social Science/Centre for Asian Studies University of Adelaide.

Shaner, D.E. (1986). Interpreting across Boundaries: A Conference of the Society for Asian and Comparative Philosophy. Philosophy East and West, vol. 36, no. 2, April.

So, R.J. (2010). Collaboration And Translation: Lin Yutang and the Archive of Asian American Literature. Modern Fiction Studies, vol. 56, no. 1, Theorizing Asian American Fiction Special Issue (Spring). 
Van Norden, B. (2017). Taking Back Philosophy: A Multicultural Manifesto. Foreword written by J.L. Garfield. New York: Columbia University Press. Wal-dal Yang, (1982). Korean Ways, Korean Mind. Tamu Dang.

Williams, R.J. (2010). The Téchnē Whim: Lin Yutang and the Invention of the Chinese Typewriter. American Literature, $82(2)$.

Wójcik, A.I. (2010). Filozoficzne podstawy sztuki kregu konfucjańskiego. Źródta klasyczne okresu przedhanowskiego. Kraków: Wydawnictwo UJ.

Yangyang, L. (2018). Translating China to the Atlantic West: Self, other, and Lin Yutang's resistance. Atlantic Studies, 15:3.

Zepp-La Rouche, H. (2015). The New Silk Road Leads to the Future of Mankind! In the New Silk Road Becomes the World Land Bridge, Executive Intelligence Review, April 10.

Zhao, M. (2015a). China's New Silk Road Initiative. Istituto Affari Internazionali Working Papers, 15, 1-12.

Zheng, Y. (2015b). The "One Belt, One Road” Strategy Helps the World Economy Rebalance. Lianhe Zaobao - Oriental Morning Post, 8 January.

Magdalena Filipczuk - Graduate of the Inter-Faculty Individual Studies in the Humanities and the Artes Liberales. Currently a PhD student at the Jesuit University Ignatianum in Krakow. Author of scientific articles on contemporary poetry, comparative philosophy, and interdisciplinary studies on literature and philosophy. Editor and translator of books for various publishers in Poland. 